\title{
PERAN PEMBERDAYAAN WAKAF TUNAI \\ (STUDI KASUS PADA BMT AMANAH UMMAH SURABAYA)'
}

\author{
Nur Liviasari Yulma \\ Program Studi S1 Ekonomi Islam-Fakultas Ekonomi dan Bisnis-Universitas Airlangga \\ Email: nurliviasari@gmail.com \\ Sri Herianingrum \\ Departemen Ekonomi Syariah-Fakultas Ekonomi dan Bisnis-Universitas Airlangga \\ Email: Sriheria@yahoo.com
}

\begin{abstract}
:
This study aims to determine the role of Amanah Ummah BMT in cash waqf empowerment, this study also aims to determine the outcome on the empowerment of cash waqf carried out by Amanah Ummah BMT. These became the interview questions' base to determine the role of Amanah Ummah BMT in cash waqf empowerment and the success of the cash waqf empowerment. This study uses qualitative approach with descriptive methods. Subjects in this study is the Manager of Surabaya Amanah Ummah BMT and the mauquf alaih who receive cash waqf.Based on the research results indicate that the role of the Amanah Ummah BMT as fund-collecting institution also as cash waqf Nazhir can be considered well because it can collect, manage and distribute cash waqf right on target. It can be seen from how the success indicators of the cash waqf empowerment program by Amanah Ummmah BMT are fulfilled.

Keywords: Cash Waqf, Mauquf Alaih Empowerment, Amanah Ummah BMT, Empowerment Indicators
\end{abstract}

\section{PENDAHULUAN}

Harta merupakan salah satu karunia Allah SWT yang diberikan untuk kesejahteraan manusia. Keberadaannya bagi manusia sangat penting sebagai salah satu penopang kelangsungan hidup. Namun bukan berarti harta adalah tujuan akhir dalam kehidupan manusia, karena ia hanya sebagai sarana untuk mencari kehidupan yang abadi yaitu diakhirat nanti. Maka Allah pun memberikan peraturan-peraturan syar'i yang harus diikuti dan ditaati oleh manusia dalam mengamalkan harta yang dimilikinya.

Kepemilikan harta benda
mengandung prinsip bahwa semua
benda hakikatnya adalah milik Allah.

Kepemilikan dalam ajaran Islam disebut

juga amanah yang mengandung arti bahwa harta yang dimiliki harus dipergunakan sesuai dengan ketentuan yang diatur oleh Allah. Konsep tersebut sesuai dengan firman Allah dalam QS. Al Maidah (5) ayat 120 yaitu:

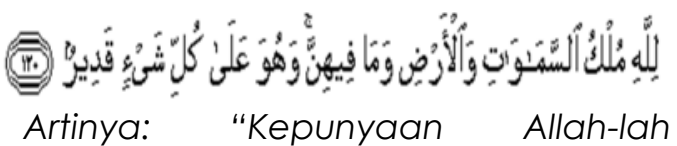
kerajaan langit dan bumi dan apa yang ada di dalamnya; dan Dia Maha Kuasa atas segala sesuatu." (QS. Al Maidah (5) :120)

Kandungan dari ayat diatas ialah kepemilikan harta benda dalam Islam harus disertai dengan tanggung jawab moral. Allah yang menciptakannya dan yang mengaturnya dengan ketetapan takdir, ketetapan syar'inya (berupa syari'at

1) Jurnal ini merupakan bagian dari skripsi Nur Liviasari Yulma, nim 04121 1431017, yang diuji pada Mei 2016 
Yulma, et al/Jurnal Ekonomi Syariah Teori dan Terapan Vol. 3 No. 11 November 2016: 856-871; PERAN PEMBERDAYAAN WAKAF TUNAI (STUDI KASUS PADA BMT AMANAH UMMAH SURABAYA)

yang dibuat-Nya) dan ketetapan jazaa'inya (adanya pembalasan terhadap amal yang dikerjakan manusia). Oleh karena itu, tidak ada yang melemahkan-Nya, bahkan semuanya tunduk kepada kehendak-Nya. Termasuk di antara kekuasaanNya adalah memberikan balasan kepada orang yang benar dan menyiksa orang yang berdusta.

Kemudian diayat lain dijelaskan bagaimana kita sebagai manusia harus saling berbagi satu sama lain yaitu terdapat pada QS. Al-Hadid (57) ayat 7 yaitu:
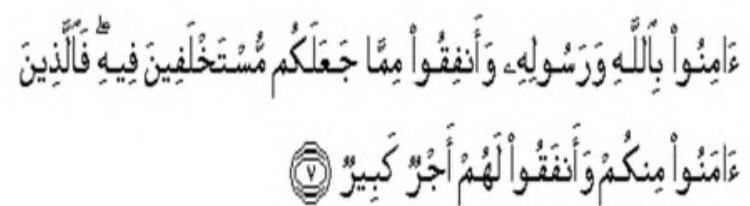

Artinya: "Berimanlah kamu kepada Allah dan Rasul-Nya dan nafkahkanlah sebagian dari hartamu yang Allah telah menjadikan kamu menguasainya Maka orang-orang yang beriman di antara kamu dan menafkahkan (sebagian) dari hartanya memperoleh pahala yang besar." (QS. Al-Hadid (57): 7)

Allah memerintahkan hambahamba-Nya beriman kepada Allah dan Rasul-Nya. Demikian pula memerintahkan mereka berinfak di jalan-Nya dari harta yang Dia jadikan pada tangan mereka dan menjadikan mereka menguasainya agar Dia melihat apa yang mereka lakukan dengannya. Setelah Dia memerintahkan demikian, Dia mendorong mereka untuk melakukannya dengan menyebutkan pahala bagi orang yang melakukannya. Kemudian yang dimaksud dengan menguasai di sini ialah penguasaan yang bukan secara mutlak. Hak milik pada hakikatnya adalah pada Allah. Oleh karena itu, manusia menginfakkan hartanya harus mengikuti hukum-hukum yang telah disyariatkan Allah, karena itu tidak boleh kikir dan boros.

Kaitannya dengan dua ayat diatas maka disini dapat ditarik kesimpulan bahwa harta yang diberikan Allah kepada manusia dibumi hanyalah titipan dan manusia harus memberi kepada sesamanya. Salah satu instrumen untuk membagikan atau menyalurkan harta kepada yang tidak mampu dapat dilakukan dengan cara berwakaf.

Menurut Darwanto (2012) wakaf sebagai satu instrumen ekonomi dalam kehidupan muslim yang mempunyai tujuan untuk mensejahterakan masyarakat. Wakaf juga dipandang sebagai sebentuk instrumen unik yang lebih mendasarkan pada unsur kebijakan (birr), kebaikan (ihsan) dan persaudaraan (ukhuwah). Sehingga mengeluarkan wakaf selain beribadah juga mempunyai dimensi membantu saudara yang membutuhkan.

Selain itu pada era modern ini, wakaf telah mengalami perkembangan yang sangat pesat, dimana terdapat bentuk wakaf tunai yang telah dipandang sebagai salah satu solusi yang dapat membuat wakaf menjadi lebih produktif. Dalam paradigma baru sekarang ini 
Yulma, et al/Jurnal Ekonomi Syariah Teori dan Terapan Vol. 3 No. 11 November 2016: 856-871; PERAN PEMBERDAYAAN WAKAF TUNAI (STUDI KASUS PADA BMT AMANAH UMMAH SURABAYA)

wakaf bukan hanya pada barang yang tidak bergerak saja, tapi juga pada barang yang bergerak termasuk uang yang disebut dengan wakaf tunai, wakaf produktif dan istilah lainnya. Wakaf tunai adalah wakaf yang dilakukan orang, sekelompok orang, lembaga atau badan hukum dalam bentuk uang tunai. Dengan demikian, wakaf tunai merupakan salah satu bentuk wakaf yang diserahkan oleh seorang wakif kepada nazir dalam bentuk vang kontan.

$$
\text { Rozalinda (2015) mengatakan }
$$

bahwa wakaf dan zakat bila dikelola secara produktif dapat dimanfaatkan untuk meningkatkan taraf hidup masyarakat. Itu berarti wakaf dapat menjadi sumber pendanaan dari umat untuk umat, baik untuk kepentingan keagamaan, sosial, maupun ekonomi. Untuk pemahaman terhadap fungsi wakaf perlu disosialisasikan dan menjadi gerakan kolektif seluruh umat dalam rangka memperbaiki ekonomi umat.

Sejalan dengan hal tersebut, Habib Ahmed (2014) dalam Rozalinda (2015) berpendapat, pengelolaan wakaf dapat menunjukkan pengelolaan wakaf yang lebih efektif bila dilakukan oleh nazhir organisasi nonprofit, dengan status badan hukum yang terpercaya. Menurut peneliti Islamic Research an Training Institution (IRTI) ini, keadaan tersebut berbeda dengan pengelola wakaf yang berasal dari pemerintah, dengan seorang manajer professional yang dapat membuat inisiatif untuk meningkatkan nilai dan keuntungan wakaf.

Hal senada juga diungkap Dian Masyita (2005) yang menyebut surveynya menyimpulkan, kebanyakan masyarakat memang tidak percaya terhadap pemerintah untuk mengelola dan mengawasi aktivitas investasi wakaf uang. Hal itu disebabkan manajemen wakaf vang melibatkan jumlah dana wakaf yang besar. Kebanyakan dari masyarakat merekomendasikan jika suatu institusi khusus dibentuk untuk mengelola wakaf vang, harus mampu mendeteksi ketidakjujuran manajer wakaf uang (nazhir). Oleh karena itu perlu mendesain suatu instrument yang mampu mengawasi manajemen dana wakaf uang. Model ini didesain sebagai alat kendali yang mampu mendeteksi kesalahan manusia dalam pengambilan keputusan baik salah urus maupun ketidakjujuran dengan cepat. Wakif dan mayarkat dapat mengawasi aluran kas dan investasi wakaf vang jika terjadi kejangalan dan ketidakjujuran.

Kemudian apabila ditinjau dari potensi wakaf uang jumlah umat Islam di Indonesia merupakan aset terbesar untuk penghimpunan dan pengembangan wakaf vang. Jika wakaf uang dapat diimplementasikan maka akan terdapat dana potensial yang dapat dipergunakan bagi kemaslahatan umat. Berdasarkan asumsi Nafis (2009)jika 20 juta umat Islam Indonesia mau mengumpulkan wakaf vang senilai Rp 100 ribu setiap bulan, 
Yulma, et al/Jurnal Ekonomi Syariah Teori dan Terapan Vol. 3 No. 11 November 2016: 856-871; PERAN PEMBERDAYAAN WAKAF TUNAI (STUDI KASUS PADA BMT AMANAH UMMAH SURABAYA)

maka dana yang terkumpul berjumlah Rp 24 triliun setiap tahun. Jika 50 juta orang yang berwakaf, maka setiap tahun akan terkumpul dana wakaf sebesar Rp 60 triliun. Jika saja terdapat 1 juta umat muslim yang mewakafkan dananya sebesar Rp 100.000 per bulan, maka akan diperoleh pengumpulan dana wakaf sebesar Rp 100 miliar setiap bulannya (Rp 1,2 triliun per tahun).

Sementara menurut Mustafa Edwin Nasution (2006) dalam Rozalinda (2015)tentang potensi wakaf di Indonesia dengan jumlah umat muslim yang dermawan diperkirakan sebesar 10 juta jiwa dengan rata-rata penghasilan Rp 500.000 hingga $\mathrm{Rp}$ 10.000.000, maka paling tidak akan terkumpul dana sekitar 3 triliun per tahun dari dana wakaf seperti perhitungan tabel berikut:

Tabel 1.

Potensi Wakaf Uang Tahun 2006

\begin{tabular}{|l|l|l|l|l|}
\hline $\begin{array}{c}\text { Tingkat } \\
\text { Penghasilan/bulan }\end{array}$ & $\begin{array}{c}\text { Jumlah } \\
\text { Muslim }\end{array}$ & $\begin{array}{c}\text { Besar } \\
\text { wakaf/bulan }\end{array}$ & $\begin{array}{c}\text { Potensi } \\
\text { wakaf } \\
\text { uang/bulan }\end{array}$ & $\begin{array}{c}\text { Potensi } \\
\text { wakaf } \\
\text { uang/tahun }\end{array}$ \\
\hline Rp 500.00 & 4 juta & Rp 5.000 & Rp 20 milyar & $\begin{array}{l}\text { Rp 240 } \\
\text { milyar }\end{array}$ \\
\hline Rp 1 juta-2juta & 3 juta & Rp 10.000 & Rp 30 milyar & $\begin{array}{l}\text { Rp 360 } \\
\text { milyar }\end{array}$ \\
\hline Rp 2 juta-5juta & 2 juta & Rp 50.000 & $\begin{array}{l}\text { Rp 100 } \\
\text { milyar }\end{array}$ & Rp 1,2 triliun \\
\hline$>$ Rp 5 juta & 1 juta & Rp 100.000 & $\begin{array}{l}\text { Rp 100 } \\
\text { milyar }\end{array}$ & $R p 1,2$ triliun \\
\hline & \multicolumn{7}{|c|}{ Total } & $R p 3$ trilliun \\
\hline
\end{tabular}

Sumber : Mustafa E Nasution (2006) dalam Rozalinda (2015)

Dalam kaitannya dengan hal diatas yang perlu diteliti lebih dalam adalah tentang bagaimana pemberdayaan wakaf tunai yang dilakukan oleh lembaga pengelola wakaf. Untuk melihat dan membuktikan secara langsung proses wakaf tunai yang tejadi peneliti mengambil contoh kasus pada Koperasi Jasa Kevangan Syariah BMT Amanah Ummah Surabaya. Koperasi Jasa Keuangan Syariah ini didirikan oleh 14 orang pemuda lulusan short course "Perbankan Syariah" yang kemudian mengumpulkan modal hingga Rp 2.850.000,- (dua juta delapan ratus lima puluh ribu rupiah) kini BMT Amanah Ummah sudah berkembang terus dan sekarang sudah menjadi lembaga yang cukup besar. Dalam kaitannya dengan latar belakang diataas, BMT Amanah Ummah juga memiliki produk wakaf tunai yang kebanyakan mereka salurkan di pondok pesantren. Data menunujukkan hingga tahun 2015 mereka telah mengumpulkan dana wakaf tunai sebanyak 200juta rupiah dan masih ada dana investasi dari wakaf tunai yang yang kurang lebih memiliki nominal sebesar 100 juta rupiah.

Memang program wakaf tunai pada BMT Amanah Ummah belom lama berjalan yaitu baru 3 tahun. Namun berdasarkan data yang diperoleh hal tersebut terus meningkat. Dan yang menarik lagi pemberdayaan wakaf tunai yang dilakukan oleh BMT Amanah Ummah ini dititik beratkan pada Community Development dan Empowering masyarakat. Peneliti ingin menggali lebih dalam lagi bagaimana proses dan hasil dari pemberdayaan yang dilakukan oleh BMT Amanah Ummah. 
Yulma, et al/Jurnal Ekonomi Syariah Teori dan Terapan Vol. 3 No. 11 November 2016: 856-871; PERAN PEMBERDAYAAN WAKAF TUNAI (STUDI KASUS PADA BMT AMANAH UMMAH SURABAYA)

Berdasarkan latar belakang di atas dapat dirumuskan pokok permasalahan, bagaimana peran pemberdayaan mauquf alaih melalui wakaf tunai yang dilakukan oleh BMT Amanah Ummah dan bagaimana keberhasilan pemberdayaan wakaf tunai BMT Amanah Ummah.

Tujuan dari penelitian ini adalah mengetahui peran BMT Amanah Ummah dalam melakukan pemberdayaan wakaf tunai dan mengetahui keberhasilan pemberdayaan wakaf tunai BMT Amanah Ummah

\section{LANDASAN TEORI}

Menurut UU No. 41 Tahun 2004 tentang Wakaf, Pasal 11, wakaf tunai atau wakaf uang (cash wagf atau wagf alnuqud) merupakan salah satu wakaf benda bergerak yang dispesifikasi berupa vang. Wakaf tunai adalah wakaf yang dilakukan seseorang, kelompok orang, lembaga atau badan hukum dalam bentuk uang tunai, termasuk dalam pengertian vang adalah surat berharga. Wakaf tunai merupakan bentuk wakaf produktif dengan mekanisme investasi dana wakaf dan menyalurkan hasil dari pokok modal yang diinvestasikan. Membandingkannya dengan wakaf tanah misalnya, wakaf tanah hanya dinikmati oleh masyarakat yang berdomisili di sekitar harta wakaf tersebut berada. Sementara masyarakat miskin berdomisili di berbagai tempat, sehingga dibutuhkan sumber pendanaan baru yang tidak terikat tempat dan waktu.
Sebab uang bersifat fleksibel dan tidak mengenal batas wilayah pendistribusian.

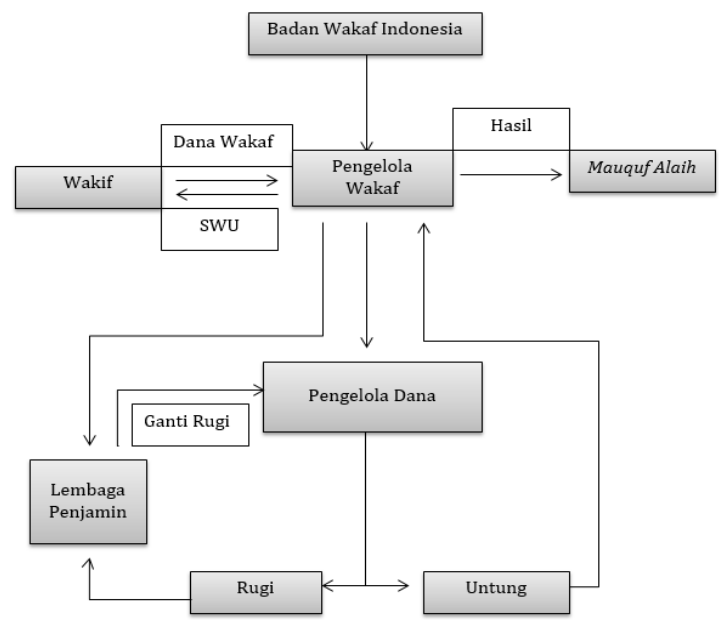

Sumber: Jurnal Model Bank Wakaf di Indonesia dalam Potensinya untuk Mengembangkan Wakaf Uang dan Mengatasi Kemiskinan (2015)

Gambar 1.

Skema Pengelolaan dan Penyaluran Hasil Wakaf Uang bank Wakaf Indonesia

Berkenaan dengan pemaknaan konsep pemberdayaan masyarakat, Ife (2008) menyatakan bahwa:

"Empowerment is a process of helping disadvantaged groups and individual to compete more effectively with other interests, by helping them to learn and use in lobbying, using the media, engaging in political action, understanding how to "work the system, ' and so on."

Definisi tersebut mengartikan konsep pemberdayaan (empowerment) sebagai upaya memberikan otonomi, wewenang, dan kepercayaan kepada setiap individu dalam suatu organisasi, serta mendorong mereka untuk kreatif agar dapat menyelesaikan tugasnya sebaik mungkin. Kemudian jika dilihat dari proses operasionalinya, maka ide 
Yulma, et al/Jurnal Ekonomi Syariah Teori dan Terapan Vol. 3 No. 11 November 2016: 856-871; PERAN PEMBERDAYAAN WAKAF TUNAI (STUDI KASUS PADA BMT AMANAH UMMAH SURABAYA)

pemberdayaan memiliki dua kecenderungan, antara lain:

1. Kecenderungan primer, yaitu kecenderungan proses yang memberikan atau mengalihkan sebagian kekuasaan, kekuatan, atau kemampuan (power) kepada masyarakat atau individu menjadi lebih berdaya. Proses ini dapat dilengkapi pula dengan upaya membangun asset material guna mendukung pembangunan kemandirian mereka melalui organisasi.

2. Kecenderungan sekunder, yaitu kecenderungan yang menekankan pada proses memberikan stimulasi, mendorong atau memotivasi individu agar mempunyai kemampuan atau keberdayaan untuk menentukan apa yang menjadi pilihan hidupnya melalui proses dialog.

Dua kecenderungan tersebut memberikan (pada titik ekstrem) seolah berseberangan, namun seringkali untuk mewujudkan kecenderungan primer harus melalui kecenderungan sekunder terlebih dahulu.

Menurut Sumodiningrat (1999), dalam upaya memberdayakan masyarakat dapat dilihat dari tiga sisi, yaitu:

Pertama, menciptakan suasana atau iklim yang memungkinkan potensi masyarakat berkembang (enabling). Disini titik tolaknya adalah pengenalan bahwa setiap manusia, setiap masyarakat, memiliki potensi yang dapat dikembangkan. Artinya, tidak ada masyarakat yang sama sekali tanpa daya, karena jika demikian akan sudah punah. Pemberdayaan adalah upaya untuk membangun daya itu, dengan mendorong, memotivasikan, dan membangkitkan kesadaran akan potensi yang dimilikinya serta berupaya untuk mengembangkannya.

Kedua, memperkuat potensi atau daya yang dimiliki masyarakat (empowering). Dalam rangka ini diperlukan langkah-langkah lebih positif, selain dari hanya menciptakan iklim dan suasana. Perkuatan ini meliputi langkahlangkah nyata, dan menyangkut penyediaan berbagai masukan (input),serta pembukaan akses ke dalam berbagai peluang (opportunities) yang akan membuat masyarakat menjadi berdaya. Pemberdayaan bukan hanya meliputi penguatan individu anggota masyarakat, tetapi juga pranatapranatanya. Menanamkan nilai-nilai budaya modern, seperti kerja keras, hemat, keterbukaan, dan kebertanggungjawaban adalah bagian pokok dari upaya pemberdayaan ini. Demikian pula pembaharuan institusiinstitusi sosial dan pengintegrasiannya ke dalam kegiatan pembangunan serta peranan masyarakat di dalamnya. Yang terpenting disini adalah peningkatan partisipasi rakyat dalam proses pengambilan keputusan yang menyangkut diri dan masyarakatnya. Oleh karena itu, pemberdayaan masyarakat 
Yulma, et al/Jurnal Ekonomi Syariah Teori dan Terapan Vol. 3 No. 11 November 2016: 856-871; PERAN PEMBERDAYAAN WAKAF TUNAI (STUDI KASUS PADA BMT AMANAH UMMAH SURABAYA)

amat erat kaitannya dengan pemantapan, pembudayaan, pengamalan demokrasi.

Ketiga, memberdayakan memiliki pula arti melindungi. Dalam proses pemberdayaan, harus dicegah yang lemah menjadi bertambah lemah, oleh karena kekurang berdayaan dalam menghadapi yang kuat. Oleh karena itu, perlindungan dan pemihakan kepada yang lemah amat mendasar sifatnya dalam konsep pemberdayaan masyarakat. Melindungi tidak berarti mengisolasi atau menutupi dari interaksi, karena hal itu justru akan mengerdilkan yang kecil dan melunglaikan yang lemah. Melindungi harus dilihat sebagai upaya untuk mencegah terjadinya persaingan yang tidak seimbang, serta eksploitasi yang kuat atas yang lemah. Pemberdayaan masyarakat bukan membuat masyarakat menjadi makin tergantung pada berbagai program pemberian (charity). Karena, pada dasarnya setiap apa yang dinikmati harus dihasilkan atas usaha sendiri.

Dengan demikian tujuan akhirnya adalah memandirikan masyarakat, memampukan, dan membangun kemampuan untuk memajukan diri ke arah kehidupan yang lebih baik secara berkesinambungan.

Terkait dengan kriteria keberhasilan yang digunakan untuk suatu proses evaluasi, Feurstein (1990) dalam Adi (2002) mengajukan beberapa indikator yang perlu dipertimbangkan. Indikator dibawah ini adalah Sembilan indikator yang paling sering digunakan untuk mengevaluasi keberhasilan suatu kegiatan pemberdayaan yaitu :

a. Indikator Ketersediaan Indikator ini melihat apakah unsur yang seharusnya ada dalam suatu proses itu benar benar ada.

b. Indikator Relevansi Indikator ini menunjukkan seberapa relevan atau tepatnya suatu teknologi atau layanan yang ditawarkan.

c. Indikator Keterjangkauan Indikator ini melihat apakah layanan yang ditawarkan masih berada dalam jangkauan pihak pihak yang membutuhkan.

d. Indikator Pemanfaatan Indikator ini melihat seberapa banyak suatu layanan yang diberi pihak pemberi layanan diterapkan atau dimanfaatkan kelompok sasaran.

e. Indikator Cakupan Indikator ini menunjukkan proporsi orang-orang yang membutuhkan sesuatu dan menerima layanan tersebut.

f. Indikator Kualitas Indikator ini menunjukkan kualitas dari layanan yang disampaikan ke kelompok sasaran.

g. Indikator Upaya Indikator ini menggambarkan berapa banyak upaya yang sudah ditanamkan dalam rangka mencapai tujuan

h. Indikator Efiesiensi 
Yulma, et al/Jurnal Ekonomi Syariah Teori dan Terapan Vol. 3 No. 11 November 2016: 856-871; PERAN PEMBERDAYAAN WAKAF TUNAI (STUDI KASUS PADA BMT AMANAH UMMAH SURABAYA)

Indikator ini menunjukkan apakah sumber daya dan aktivitas yang dilaksanakan guna mencapait tujuan dimanfaatkan secara efisien, atau tidak memboroskan sumber daya yang ada dalam upaya mencapai tujuan.

i. Indikator Dampak

Indikator ini melihat apakah sesuatu yang dilakukan oleh pihak pemberi layanan benar-benar memberian sesuatu perubahan.

Adapun tujuan kegiatan dalam jangka panjangnya adalah kemandirian yaitu pengembangan kapasitas dan pengitegrasian masyarakat yang dititikberakan pada tujuan proses.

\section{METODE PENELITIAN}

\section{Lokasi Penelitian}

Penelitian ini dilakukan di Koperasi Jasa Keuangan Syariah BMT Amanah Ummah Surabaya. Peneliti memilih melakukan penelitian di Koperasi Jasa Kevangan Syariah BMT Amanah Ummah Surabaya dikarenakan ingin mengetahui bagaimanakah peran wakaf tunai dalam pemberdayaan mauquf alaih. BMT Amanah Ummah adalah baitul maal yang dianggap merupakan lembaga yang berkompeten dan sudah berkecimpung dalam penyaluran wakaf tunai.

\section{Pendekatan Penelitian}

Berdasarkan judul dan rumusan masalah, penelitian yang penulis angkat adalah penelitian kualitatif dengan metode diskriptif. Metode penelitian kualitatif adalah metode penelitian yang digunakan untuk meneliti pada kondisi obyek yang alamiah yakni obyek yang berkembang apa adanya, tidak dimanipulasi oleh peneliti, dan kehadiran peneliti tidak mempengaruhi dinamika pada obyek tersebut dimana peneliti adalah instrumen kunci. Dalam penelitian kualitatif rumusan masalah merupakan fokus penelitian yang masih besifat sementara dan akan berkembang setelah peneliti masuk lapangan atau situasi sosial tertentu dengan maksud untuk memahami gejala sosial yang kompleks.

Menurut Sugiyono (2007) penelitian dengan metode deskriptif adalah melukiskan dan menafsirkan keadaan sekarang ini berkenaan dengan kondisi yang ada dan memusatkan dari pada pemecahan masalah-masalah yang ada pada masa sekarang, terhadap masalah yang aktual. Menurut Moleong (2008) metode deskriptif adalah berupa katakata tertulis atau lisan dari fenomena sosial yang diamati baik dengan observasi, wawancara maupun dokumentasi yang relevan. Berdasarkan uraian tersebut dapat dikemukakan bahwa penelitian deskriptif ini berusaha menggambarkan objek penelitian berdasarkan fakta dan data serta kejadian berusaha menghubungkan kejadian-kejadian atau objek penelitian sekaligus menganalisanya berdasarkan konsep-konsep yang telah dikembangkan sebelumnya sehingga memudahkan peneliti dalam memecahkan masalah. 
Yulma, et al/Jurnal Ekonomi Syariah Teori dan Terapan Vol. 3 No. 11 November 2016: 856-871; PERAN PEMBERDAYAAN WAKAF TUNAI (STUDI KASUS PADA BMT AMANAH UMMAH SURABAYA)

\section{Subjek Penelitian}

Subjek peneliti dalam penelitian ini adalah Responden adalah orang yang merespon atau menjawab pertanyaan yang bisa memberikan data berupa jawaban lisan melalui wawancara, adapun yang menjadi responden dalam penelitian ini adalah Manajer Koperasi Jasa Kevangan Syariah BMT Amanah Ummah Surabaya dan mauquf alaih yang menerima wakaf tunai.

\section{Fokus Penelitian}

Fokus Penelitian Moleong (2008), berpendapat bahwa penetapan fokus penelitian atau masalah dalam penelitian kualitatif bagaimana pun akhirnya akan dipastikan sewaktu peneliti sudah berada di area atau lapangan penelitian. Dengan kata lain, walaupun rumusan masalah sudah cukup baik dan telah dirumuskan atas dasar penelaahan kepustakaan dan dengan ditunjang oleh sejumlah pengalaman tertentu, bisa terjadi situasi di lapangan tidak memungkinkan peneliti untuk meneliti masalah itu. Dengan demikian kepastian tentang fokus dan masalah itu yang menentukan adalah keadaan di lapangan.

Fokus penenlitian dalam penelitian kualitatif berkaitan erat dengan rumusan masalah, dimana rumusan masalah penelitian dijadikan acuan dalam menentukan fokus penelitian. Dalam hal ini fokus penelitian dapat berkembang atau berubah sesuai dengan perkembangan masalah penelitian di lapangan. Hal tersebut sesuai dengan sifat pendekatan kualitatif yang lentur, yang mengikuti pola pikir yang empirical induktif, dimana segala sesuatu dalam penelitian ini ditentukan dari hasil akhir pengumpulan data yang mencerminkan keadaan yang sebenarnya.

Dalam penelitian ini yang menjadi fokus penelitian adalah peran pemberdayaan wakaf tunai dalam pemberdayaan mauquf alaih. Fokus ini diambil untuk mengatahui peran dari pemberdayaan wakaf tunai yang ada pada BMT Amanah Ummah terhadap mauquf alaih serta melihat tingkat keberhasilan dari pemberdayaan wakaf tunai tersebut.

\section{Teknik Pengambilan Sampel}

Dalam penelitian kualitatif ini penulis menggunakan teknik purposive sampling. Menurut Sugiyono (2007) purposive sampling adalah teknik pengambilan sampel sumber data dengan pertimbangan tertentu yakni sumber data dianggap paling tahu tentang apa yang diharapkan, sehingga mempermudah peneliti menjelajahi obyek atau situasi sosial yang sedang diteliti, yang menjadi kepedulian dalam pengambilan sampel penelitian kualitatif adalah tuntasnya pemerolehan informasi dengan keragaman variasi yang ada, bukan pada banyak sampel sumber data. Lincoln dan Guba (1985) dalam Sugiyono (2007) mengemukakan bahwa penentuan sampel dalam penelitian kualitatif tidak didasarkan pada perhitungan statistik. 
Yulma, et al/Jurnal Ekonomi Syariah Teori dan Terapan Vol. 3 No. 11 November 2016: 856-871; PERAN PEMBERDAYAAN WAKAF TUNAI (STUDI KASUS PADA BMT AMANAH UMMAH SURABAYA)

Sampel yang dipilih berfungsi untuk mendapatkan informasi yang maksimum.

\section{Teknik Pengumpulan Data}

Teknik pengumpulan data merupakan langkah yang paling strategis dalam penelitian, karena tujuan utama dari penelitian adalah mendapatkan data, tanpa mengetahui teknik pengumpulan data maka peneliti tidak akan mendapatkan data yang memenuhi standar data yang ditetapkan, dalam penelitian ini penulis menggunakan teknik pengumpulan data sebagai berikut :

1. Observasi

Peneliti menggunakan observasi metode terus terang atau tidak tersamar dimana peneliti dalam melakukan pengumpulan data menyatakan terus terang kepada sumber data, bahwa sedang melakukan penelitian.

2. Wawancara

Peneliti menggunakan metode wawancara Semiterstruktur yakni menurut Sugiyono (2007) metode wawancara semi terstruktur, dimana dalam pelaksanaannya lebih bebas.Dalam melakukan wawancara peneliti akan mendengarkan secara teliti dan mencatat apa yang akan dikemukakan oleh informan. Dalam pelaksanaanya penulis akan mewawancarai pihak-pihak yang berhubungan dengan wakaf tunai.

\section{Dokumentasi}

Peneliti memanfaatkan arsip atau data-data yang berhubungan dengan sejarah berdirinya Koperasi Jasa Kevangan Syariah BMT Amanah Ummah
Surabaya, struktur organisasi, tujuan, jumlah pengurus, dan data historis perusahaan utamanya mengenai wakaf tunai.

4. Triangulasi

Peneliti mengumpulkan data yang sekaligus menguji kredibilitas data, yaitu mengecek kredibilitas data dengan berbagai teknik pengumpulan data dan berbagai sumber. Triangulasi teknik, berarti peneliti menggunakan teknik pengumpulan data yang berbeda(beda untuk mendapatkan data dari sumber yang sama. Peneliti menggunakan observasi partisipatif, wawancara mendalam, dan dokumentasi untuk sumber data yang sama secara serempak.

Teknik Analisis

Teknik analisa data yang digunakan peneliti dalam penelitian ini adalah analisis deskriptif yang dikumpulkan dan akan dijabarkan dengan uraian sistematis untuk mengetahui peran wakaf tunai dalam pemberdayaan mauquf alaih (Studi pada Koperasi Jasa Keuangan Syariah BMT Amanah Ummah Surabaya), selanjutnya dari penyaluran wakaf tunai tersebut akan dinilai baik buruknya berdasarkan standar atau target yang telah ditetapkan oleh perusahaan

\section{HASIL DAN PEMBAHASAN}

KJKS BMT Amanah Ummah merupakan salah satu lembaga yang saat ini melakukan pengelolaan terhadap wakaf tunai. Mereka sudah melakukan 
Yulma, et al/Jurnal Ekonomi Syariah Teori dan Terapan Vol. 3 No. 11 November 2016: 856-871; PERAN PEMBERDAYAAN WAKAF TUNAI (STUDI KASUS PADA BMT AMANAH UMMAH SURABAYA)

penghimpunan dana wakaf tunai semenjak akhir tahun 2013. Pada awal tahun 2015 mereka mendapatkan sertifikat sebagai nazhir dari Badan Wakaf Indonesia. Adanya program wakaf tunai di BMT Amanah Ummah dilatarbelakangi dengan melihat tingginya keberhasilan wakaf tunai di Malaysia, sehingga dianggap memungkinkan pula diterapkan di Indonesia khususnya pada BMT Amanah Ummah.

Untuk 2 tahun pertama BMT Amanah Ummah membuka program wakaf tunai ini peminatnya masih rendah karena kurangnya pengetahuan masyarakat tentang mengenai apa itu wakaf tunai. Karena masyrakat mengira bahwa wakaf yang selama ini berlangsung hanyalah wakaf berupa benda tidak bergerak saja seperti sebidang tanah atau masjid. Hal ini dikarenakan pemahaman masyarakat belom mengetahui tentang adanya wakaf benda bergerak yaitu wakaf tunai. Dalam pemahaman wakaf yang berubah sebenarnya bukan bendanya melainkan nilainya yang tidak boleh berkurang, pemahaman inilah yang ingin diedukasi oleh BMT Amanah Ummah ke masyarakat.

Terdapat 2 tipe wakif yang ada dalam BMT Amanah Ummah yaitu wakif yang ingin menerima laporan kevangannya setiap beberapa periode dan wakif yang acuh tak acuh setelah mereka memberikan dan wakaf tunainya. Sebelum seluruh dana wakaf tunai mereka serahkan kepada BMT Amanah
Ummah juga terdapat formulir yang harus diisi oleh wakif yang berisi tentang perjanjian dan sebagai bentuk akad bahwa vang tersebut sudah diserahkan dan seutuhnya diwakafkan melalui BMT Amanah Ummah yang berperan sebagai Nazhir disini. Kemudian terdapat hal yang menarik dalam praktik wakaf tunai dalam BMT Amanah Ummah ini adalah mereka tidak menggunakan lembaga penjamin untuk menjaminkan nilai wakaf tunai yang ada mereka. Mereka menjaminkan atas nama lembaga BMT Amanah Ummah sendiri dalam menjaga nilai wakafnya. Dan hingga saat ini nilai wakaf yang mereka jaminkan tersebut memang belum pernah berkuran nilainya dari nilai wakaf yang pertama kali disetorkan kepada BMT Amanah Ummah.

Peran wakaf tunai yang dikelola oleh BMT Amanah Ummah dalam peningkatan ekonomi mauquf alaih untuk saat ini memang belum terasa secara output atau hasil akhir. Yang dimaksud dengan output adalah peningkatan jumlah asset dari mauquf alaih. Hal tersebut belum dapat terhitung secara signifikan karena program wakaf tunai dalam BMT Amanah Ummah masih tergolong baru, yaitu baru berjalan sekitar 2 tahun.

BMT Amanah Ummah memiliki proyeksi keuangan kedepannya program wakaf tunai ini dapat terlihat hasilnya sekitar 10 tahun kemudian sudah dapat berkembang hingga $100 \%$ dari hasil wakaf tunai yang ada sekarang. Apabila melihat 
Yulma, et al/Jurnal Ekonomi Syariah Teori dan Terapan Vol. 3 No. 11 November 2016: 856-871; PERAN PEMBERDAYAAN WAKAF TUNAI (STUDI KASUS PADA BMT AMANAH UMMAH SURABAYA)

hasil observasi dilapangan dengan program pemberdayaan masyarakat yang ada sekarang peran wakaf tunai dalam peningkatan ekonomi mauquf alaih, yang dalam kasus ini adalah pesantren Roudlutul Hikam, kini pondok pesantren sudah berhasil mengembangbiakkan kambing yang awalnya 3 ekor sekarang menjadi 6 ekor, dan selain itu pihak pondok pesantren sudah dapat mengelola kotoran kambing yang hasil olahannya digunakan untuk membiayai perawatan kambing, selain itu kini pesantren Roudlutul Hikam sedang berusaha mengembangkan untuk membuat teknologi pangan ternak sendiri agar jangka panjangnya dapat lebih mandiri lagi.

Menurut Feustein (1990) dalam Adi (2002) menjabarkan ada Sembilan indicator yang sering digunakan untuk mengevaluasi keberhasilan suatu kegiatan pemberdayaan yaitu indikator ketersediaan, indikator relevansi, indikator keterjangkauan, indikator pemanfaatan, indikator cakupan, indikator kualitas, indikator upaya, indikator efisiensi, dan indikator dampak.

Dalam pengumpulan data terkait indikator-indikator menggunakan metode desain triangulasi seperti yang diungkapkan Sugiyono (2007) triangulasi adalah teknik pengumpulan data yang bersifat menggabungkan dari berbagai teknik pengumpulan data dan sumber data yang telah ada. Maka dari itu kemudian disini dari wawancara tiga informan kemudian dilanjutkan dengan observasi dan dipastikan dengan telaah dokumen/sumber literatur.

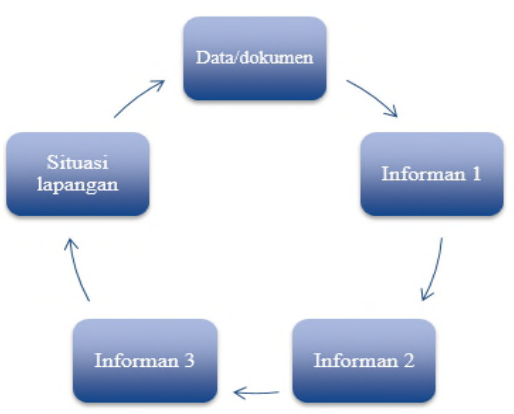

Sumber: Diolah

Gambar 2.

Model Desain Kombinasi Triangulasi Sumber dan Triangulasi Metode

Dari model desain diatas kemudian peneliti meringkas hasil triangulasi tersebut dalam tabel 2. Tabel data 2 dibuat untuk membantu peneliti dalam mengorganisir data yang berhubungan dengan pemberdayaan mauquf alaih secara berkelanjutan. Berikut hasil data tersebut.

Tabel 2.

Hasil Triangulasi Data

\begin{tabular}{|c|c|c|c|c|c|}
\hline \multicolumn{2}{|c|}{ Indikator } & \multirow{2}{*}{$\begin{array}{c}\text { Informan 1 } \\
\mathrm{x}\end{array}$} & \multirow{2}{*}{$\begin{array}{c}\text { Informan 2 } \\
\mathrm{x}\end{array}$} & \multirow{2}{*}{\begin{tabular}{c|} 
Informan 3 \\
$\sqrt{ }$
\end{tabular}} & \multirow{2}{*}{$\begin{array}{c}\begin{array}{c}\text { Hasil } \\
\text { Observasi }\end{array} \\
x \\
\end{array}$} \\
\hline Dron & $\begin{array}{l}\text { Peningkatan } \\
\text { Ekonomi }\end{array}$ & & & & \\
\hline Dampak & $\begin{array}{l}\text { Peningkatan } \\
\text { Iman }\end{array}$ & $\mathrm{x}$ & $\mathrm{x}$ & $\mathrm{x}$ & $\mathrm{x}$ \\
\hline \multirow{3}{*}{ Ketersediaan } & $\begin{array}{c}\text { Dana Wakaf } \\
\text { tunai }\end{array}$ & $\sqrt{ }$ & $\checkmark$ & v & $\checkmark$ \\
\hline & $\begin{array}{l}\text { Pengelolaan } \\
\text { Wakaf tunai }\end{array}$ & $\sqrt{ }$ & $\sqrt{ }$ & $\sqrt{ }$ & $\checkmark$ \\
\hline & $\begin{array}{l}\text { Penyaluran } \\
\text { Wakaf tunai }\end{array}$ & $\sqrt{ }$ & $\checkmark$ & $\sqrt{ }$ & $\checkmark$ \\
\hline Relevansi & $\begin{array}{c}\text { Penggunaan } \\
\text { Hasil Wakaf } \\
\text { Tunai }\end{array}$ & $\sqrt{ }$ & $\begin{array}{c}\text { Tidak } \\
\text { Berhubungan }\end{array}$ & v & $\checkmark$ \\
\hline Keterjangkauan & $\begin{array}{l}\text { Keterjangkauan } \\
\text { ketiga pihak }\end{array}$ & $\sqrt{ }$ & $\checkmark$ & $\checkmark$ & $\checkmark$ \\
\hline Pemanfaatan & $\begin{array}{c}\text { Progres } \\
\text { pemanfaatan } \\
\text { wakaf tunai }\end{array}$ & $\sqrt{ }$ & $\checkmark$ & v & $\checkmark$ \\
\hline Cakupan & $\begin{array}{c}\text { Kesesuaian } \\
\text { pemanfaatan } \\
\text { hasil wakaf } \\
\text { tunai yang } \\
\text { wakafkan }\end{array}$ & $\sqrt{ }$ & $\checkmark$ & $\sqrt{ }$ & $\checkmark$ \\
\hline Kualitas & $\begin{array}{c}\text { Dampak dan } \\
\text { tujuan Nazhir } \\
\text { dalam } \\
\text { pemberian } \\
\text { wakaf tunai }\end{array}$ & $\sqrt{ }$ & $\checkmark$ & $\sqrt{ }$ & $\checkmark$ \\
\hline Upaya & $\begin{array}{l}\text { Upaya menjaga } \\
\text { tujuan Nazhir }\end{array}$ & $\sqrt{ }$ & $\sqrt{ }$ & $\sqrt{ }$ & $\sqrt{ }$ \\
\hline Efisiesnsi & $\begin{array}{c}\text { Tidak ada } \\
\text { pemborosan } \\
\text { waktu dan dana }\end{array}$ & $\sqrt{ }$ & $\checkmark$ & $\checkmark$ & $\checkmark$ \\
\hline
\end{tabular}

Sumber: Diolah 
Yulma, et al/Jurnal Ekonomi Syariah Teori dan Terapan Vol. 3 No. 11 November 2016: 856-871; PERAN PEMBERDAYAAN WAKAF TUNAI (STUDI KASUS PADA BMT AMANAH UMMAH SURABAYA)

Berdasar hasil triangulasi yang sudah peneliti lakukan program pemberdayaan masyarakat BMT Amanah Ummah sudah mencakup delapan indikator tersebut hanya indikator dampak yang belum dapat dilihat keberhasilannya dikarenakan program pemberdayaan masyarakat yang dijalankan BMT Amanah Ummah yang masih tergolong baru. Adapun penjabaran dari kedelapan indikator lainnya adalah sebagai berikut:

a. Indikator Ketersediaan

Indikator ini melihat apakah unsur yang seharusnya ada dalam suatu proses itu benar benar ada. Unsur unsur dalam program pemberdayaan masyarakt dari BMT Amanah Ummah ini benar-benar ada yaitu dari pihak BMT Amanah Ummah sebagai pengelola program pemberdayaan kemudian pihak peternakan yang dikelola oleh bapak Khoirul Aidin sebagai pihak yang dianggap berkompeten untuk memberikan pelatihan kepada sasaran pemberdayaan, dalam studi kasus ini asaran pemberdayaan adalah pondok pesantren Roudlotul Hikam.

b. Indikator Relevansi

Indikator ini menunjukkan seberapa relevan atau tepatnya suatu teknologi atau layanan yang ditawarkan. Ditinjau dari indikator ini, program pemberdayaan wakaf tunai yang dilaksanakan oleh BMT Amanah Ummah sudah relevan dengan memberikan layanan berupa kambing kepada sasaran pemberdayaan yaitu mauquf alaih. Dapat dikatakan relevan karena karena kambing yang diberikan dapat dijadikan sarana untuk memandirikan mauquf alaih secara berkelanjutan.

c. Indikator Keterjangkauan

Indikator ini melihat apakah layanan yang ditawarkan masih berada dalam jangkauan pihak pihak yang membutuhkan. Hasil dari observasi yang telah dilakukan oleh peneliti menunjukkan bahwa layanan yang diberikan kepada mauquf alaih dapat dijangkau oleh pihak yang membutuhkan karena di lapangan peneliti melihat pihak yang memberikan layanan disini yaitu BMT Amanah Ummah mendatangi sasaran langsung sehingga pihak penerima layanan yaitu pondok pesantren Roudlotul Hikam dapat menjangkau layanan dengan sangat mudah.

d. Indikator Pemanfaatan

Indikator ini melihat seberapa banyak suatu layanan yang diberi pihak pemberi layanan diterapkan atau dimanfaatkan kelompok sasaran. Fakta dilapangan menunjukkan indikator ini sudah terpenuhi, melihat bagaimana kelompok sasaran pemberdayaan yaitu pondok pesantren Roudlutul Hikam yang baru menjalani program pemberdayaan masyarakat belom lama namun sudah dapat mengembangbiakkannya. Selain itu ada inisiatif sendiri dalam pengembangan dari hasil wakaf tunai yang diberikan oleh BMT Amanah Ummah.

e. Indikator Cakupan 
Yulma, et al/Jurnal Ekonomi Syariah Teori dan Terapan Vol. 3 No. 11 November 2016: 856-871; PERAN PEMBERDAYAAN WAKAF TUNAI (STUDI KASUS PADA BMT AMANAH UMMAH SURABAYA)

Indikator ini menunjukkan proporsi orang-orang yang membutuhkan sesuatu dan menerima layanan tersebut. Proporsi dalam program wakaf tunai ini ditentukan oleh pihak BMT Amanah Ummah, karena mereka berpegang pada konsep ekonomi multiplier effect daripada pembagian hasil wakaf tunai secara merata. Sehingga dapat memandirikan masyarakat secara luas nantinya. Jadi proporsi pemberian layanan tentu merupakan hasil dari penyaringan yang ketat dari pihak BMT Amanah Ummah selaku pengelola dana wakaf tunai.

f. Indikator Kualitas

Indikator ini menunjukkan kualitas dari layanan yang disampaikan ke kelompok sasaran. Kualitas layanan yang diberikan BMT Amanah Ummah kepada mauquf alaif dapat diberikan nilai secara baik. Karena layanan berupa pemberian kambing akan memberikan dampak yang luas dan berguna bagi masyarakat luas seperti yang sudah pada sub bab sebelumnya.

g. Indikator Upaya

Indikator ini menggambarkan berapa banyak upaya yang sudah ditanamkan dalam rangka mencapai tujuan. Tujuan dari program pemberdayaan masyarakat dari hasil wakaf tunai BMT Amanah Ummah ini sendiri adalah untuk memandirikan dan meningkatkan iman mauquf alaih. Kemudian apabila dilihat dari upaya yang diterapkan oleh BMT Amanah Ummah sudah tepat yaitu dengan terus menjalin komunikasi dan mengingatkan pihak mauquf alaih yaitu pondok Roudlutul Hikam untuk menjaga visi misi mereka yang sudah dijalin sejak awal pemberian hasil wakaf tunai.

h. Indikator Efiesiensi

Indikator ini menunjukkan apakah sumber daya dan aktivitas yang dilaksanakan guna mencapai tujuan dimanfaatkan secara efisien, atau tidak memboroskan sumber daya yang ada dalam upaya mencapai tujuan. Tingkat efisiensi yang dilakukan oleh BMT Amanah Ummah dalam program wakaf tunai yaitu pemberdayaan masyarakat disini khususnya sudah optimal karena mereka memiliki perencanaan yang jelas sebelum berinvestasi, proyeksi keuangan yang tepat dan pemilihan sasaran pemberdayaan serta tempat investasiyang sudah mereka rapatkan dalam jangka waktu tertentu.

\section{SIMPULAN}

Dari hasil pembahasan, terdapat beberapa kesimpulan dari peran pemberdayaan wakaf tunai yang sudah dijalankan oleh BMT Amanah Ummah. Kesimpulan yang dimaksud adalah :

1. Peran BMT Amanah Ummah sebagai lembaga penghimpun dana wakaf tunai sebagai nazhir dapat dikatakan sudah baik karena dapat secara jelas menghimpun, mengelola dan menyalurkan wakaf tunai secara tepat sasaran. Hal tersebut dapat dilihat dari bagaimana indikatorindikator keberhasilan dari program pemberdayaan sudah sesuai dengan 
Yulma, et al/Jurnal Ekonomi Syariah Teori dan Terapan Vol. 3 No. 11 November 2016: 856-871; PERAN PEMBERDAYAAN WAKAF TUNAI (STUDI KASUS PADA BMT AMANAH UMMAH SURABAYA)

program wakaf tunai dari BMT Amanah Ummah.

2. Program wakaf tunai yang lebih menitikberatkan pada pemberdayaan mauquf alaih memang belum bisa diukur secara fisik hasilnya namun selama 2 tahun berjalan ini program wakaf tunai menunjukkan progress yang baik dan berkembang sesuai dengan harapan dari BMT Amanah Ummah. Hal itu terlihat dari bagaimana perubahan dan mentranferan ilmu dari pihak pengelola kambing kepada pihak pondok pesantren Roudlutul Hikam sebagai mauquf alaih.

3. Kemandirian masyarakat secara ekonomi dan peningkatan kualitas iman serta takwa mauquf alaih adalah poin penting yang selalu ditekankan oleh BMT Amanah Ummah dalam tujuan jangka panjang BMT Amanah Ummah.

Saran yang dapat diberikan dari hasil penelitian adalah sebagai berikut :

1. Saran bagi BMT Amanah Ummah :

a. Sebaiknya lebih mensosialisaikan dan mengedukasi masyarakat tentang wakaf khususn wakaf tunai dalam hal ini agar dapat meningkatkan pengihimpunan dana dari masyarakat, sehingga wakaf tunai dapat lebih berperan dalam pemberdayaan masyarakat.

b. Melakukan kontrol rutin terhadap pihak pengelola dana wakaf tunai yang disini adalah peternakan kambing yang terletak di Mojoagung agar nilai wakaf tunai tidak berkurang apalagi habis

c. Sebaiknya membentuk tim khusus untuk berkonsentrasi untuk mengurusi wakaf tunai ini agar lebih fokus dalam pengelolaan wakaf tunai, karena potensi wakaf tunai di Indonesia sangatlah besar dan secara khusus melihat jumlah penduduk yang memeluk agama Islam di daerah Surabaya.

2. Saran bagi penelitian selanjutnya:

a. Agar melakukan penelitian di beberapa tahun kedepan untuk melihat hasil akhir dari pemberdayaan yang telah dilakukan oleh BMT Amanah Ummah.

b. Agar melakukan penelitian yang lebih mendalam mengenai bagaimana peran wakaf dalam pemberdayaan mauquf alaih dengan studi kasus di lembaga yang berbeda.

c. Lebih fokus melakukan penelitian pada cara menahan nilai wakaf agar tidak berkuran karena penelitian yang dilakukan dalam penelitian ini berfokus pada mauquf alaih saja.

\section{DAFTAR PUSTAKA}

Adi, Isbandi Rukmianto. 2002. Intervensi Komunitas,Pengembangan Masyarakat sebagai Upaya Pemberdayaan Masyarakat. Jakarta: PT Raja Grafindo Persada.

Darwanto. 2012. Wakaf Sebagai Alternatif Pendanaan Penguatan Ekonomi Masyarakat Indonesia. Jurnal IImu 
Yulma, et al/Jurnal Ekonomi Syariah Teori dan Terapan Vol. 3 No. 11 November 2016: 856-871; PERAN PEMBERDAYAAN WAKAF TUNAI (STUDI KASUS PADA BMT AMANAH UMMAH SURABAYA)

Manajemen dan Akuntansi Terapan.

Vol 3 Nomor 1, Mei 2012.

Havita, Gusva, 2015. Model Bank Wakaf Di Indonesia Dalam Potensinya Untuk Mengembangkan Wakaf Uang Dan Mengatasi Kemiskinan. Jurnal Ekonomi Islam: 1-16

Ife \& Frank Tesoriero. 2008. Community development: alternatif pengembangan masyarakat di era globalisasi. Australia. Pustaka pelajar.

Masyita, Dian, dkk, 2005 A Dynamic Model for Cash Waqf Management as One of The Alternative Instruments for the Poverty Alleviation in Indonesia, Boston. Moleong, Lexy J. 2008. Metodologi Penelitian Kualitatif. Bandung: Remaja Remaja Rosdakarya.

Nafis, M. Cholil. 2009. Wakaf Uang Untuk Jaminan Sosial, dalam Jurnal Al-Waqaf, Vol. II, Nomor 2,. Jakarta: BWI

Rozalinda, M.Ag., 2015. Manajemen Wakaf Produktif. Jakarta. PT Raja Grafindo Persada

Sugiyono. 2007. Statistika untuk Penelitian. Bandung : Alfabeta

Sumodiningrat, G. 1999. Pemberdayaan Masyarakat dan Jaring Pengaman Sosial Jakarta: Gramedia. 